\title{
O lugar da literatura juvenil
}

\section{distópica no polissistema literário}

\author{
brasileiro: o caso da trilogia
}

\author{
"Divergente"
}

\section{The position of juvenile dystopian}

\section{literature within the Brazilian}

\section{literary polysystem: the case of the “Divergent" trilogy}

Natália Regina da Silva*

Sandra Aparecida Faria de Almeida*

Resumo: Este artigo visa a discutir a tradução de literatura juvenil distópica no Brasil, considerando a demanda por este subgênero e sua relação direta com as escolhas do tradutor. Com base na Teoria dos Polissistemas (EVEN-ZOHAR 1990 [1978]) e nos conceitos de manipulação e patronagem (LEFEVERE 1992b), argumentamos que o

\footnotetext{
"Graduada em Letras-Bacharelado em Tradução/Inglês (UFJF) - nataliainhan@hotmail.com ** Professora Doutora do curso de Letras-Bacharelado em Tradução/Inglês e do Programa de Pós-graduação em Linguística (UFJF) - sandra.sf@gmail.com
} 
polissistema literário brasileiro sofre influência de forças externas e internas que propiciam a entrada do subgênero distopia no sistema e que a literatura juvenil, tradicionalmente periférica ao sistema literário, tende a assumir posições mais privilegiadas face ao crescente consumo do subgênero, que estimula a produção nacional. No que diz respeito às escolhas tradutórias, analisamos qualitativamente, com base em Berman (2013 [1985]), trechos dos três volumes da trilogia Divergent, de Veronica Roth. Defendemos que as escolhas do tradutor estão sujeitas às pressões dos demais sistemas que coexistem ao sistema literário, podendo, dessa forma, sofrer deformações na medida em que buscam se adequar ao polissistema-alvo.

Palavras-chave: Literatura juvenil; Distopia; Teoria dos Polissistemas; Tendências deformadoras.

Abstract: This paper is aimed at discussing the translation of young adult dystopian literature in Brazil, considering the demand for this subgenre and its direct correlation with translator's choices. Based on Polysystem Theory (EVEN-ZOHAR 1990 [1978]), and on the concepts of manipulation and patronage (LEFEVERE 1992b), we argue that the Brazilian literary polysystem faces the influence of both external and internal forces which favour the access of this subgenre to the system and that young adult literature, traditionally occupying a peripheral position, tends to gain a more central role due to the increased consumption of dystopia, which stimulates the national production. In regard to translator's choices and based on Berman (2013 [1985]), we qualitatively analyse excerpts from the three volumes of the trilogy "Divergent", by Veronica Roth, and argue that the translator is under pressure from the other systems coexisting with the literary system, with his choices resulting in deforming tendencies in an attempt to suit the target polysystem.

Keywords: Young adult literature; Dystopia; Polysystem Theory; Deforming tendencies.

\section{Introdução}

Ao longo das últimas décadas, a literatura juvenil tem ganhado cada vez mais espaço nas feiras de livros, tanto no país quanto no exterior, bem como nas prateleiras das livrarias em todo o mundo. As editoras também se desdobram para acompanhar a demanda deste público que envolve jovens de diferentes faixas etárias e até mesmo adultos, os quais se sentem atraídos por este universo singular, que mescla fantasia, horror e ficção científica em doses tão precisas que satisfazem até os mais exigentes leitores.

A literatura juvenil no Brasil é compreendida como um desdobramento natural da literatura infantil, que tem na figura de Monteiro Lobato seu maior expoente, por toda a contribuição que o renomado autor deu ao segmento de literatura infantojuvenil nacional. Especialistas classificam sua obra literária 
segundo duas linhas de pensamento: (i) a preocupação com a conquista de uma brasilidade, rompendo com convenções estereotipadas e abrindo espaço para novas ideias e formas (COELHO 1991) e (ii) uma temática que reflete a busca do conhecimento e da verdade em prol da liberdade, unindo os planos da realidade e da fantasia (CARVALHo 1985) e refutando, dessa forma, o forte viés moralizante dos contos de fadas tradicionais. Conforme observa Carvalho:

A obra infanto-juvenil de Lobato realiza-se numa unidade temática, de lugar e de personagens, considerando-se as personagens codificadoras, protagonistas, promovedoras das diversas ações e aventuras; a fixação espacial (o "Sítio"); e o tema da curiosidade científica e lúdica das crianças. Dentro desse esquema, a obra lobatiana caracterizou-se por uma constante colocação binária, e é nessa dicotomia que repousa toda a sua estrutura. A priori, ela está classificada em dois planos; o plano da realidade, que é o "Sítio", a vivência real, do cotidiano, suporte e ponto de partida de toda a fantasia, e o plano da fantasia, da função lúdica, em tempo mítico, onde se realiza o maravilhoso. (CARVALHO 1985: 136)

A contribuição de Lobato, consequentemente, está em introduzir novos valores ao universo cultural e literário de sua época, papel que desempenhou de forma magistral, tanto como autor - na criação de um repertório infantojuvenil singular, com características temáticas e estéticas inovadoras , quanto como tradutor - na inserção de clássicos da literatura universal no polissistema literário brasileiro, por meio da literatura traduzida (COELHO 1991).

Embora reconheça o caráter inovador da obra literária de Lobato, Coelho (1991: 237, grifos da autora) vai mais além, ao afirmar que "mais do que valores estabelecidos, a literatura de hoje deve propor projetos de ação e estimular a consciência reflexiva e crítica de seus leitores, a fim de que eles encontrem a sua direção e tenham capacidade para encontrar um sentido para a vida."

Nesse sentido, as literaturas infantojuvenil e juvenil, com todos os seus subgêneros e ramificações, tornam-se cada vez mais o espelho de um universo em constante mutação. É nessa perspectiva que a literatura juvenil distópica, subgênero cada vez mais explorado dentro do polissistema literário internacional, começa a conquistar espaço também no polissistema literário 
brasileiro, em especial via literatura traduzida, catalisando realidade e fantasia em uma perspectiva inversa, a da não-utopia.

\section{A distopia nos séculos XX e XXI: uma breve retrospectiva}

Para falar de distopia é preciso, primeiramente, definir o termo utopia. A palavra utopia, segundo o Minidicionário da Língua Portuguesa (2007), de Silveira Bueno, remete a uma criação poética do escritor inglês Thomas More (1480-1535), que significa um país imaginário onde tudo está organizado da melhor maneira possível, um plano teórico irrealizável, uma fantasia. Por se tratar de um projeto idealizado e fantasioso, a utopia acaba por compor uma visão altamente positiva e otimista sobre a vida, o mundo e o futuro. De acordo com Fromm (1961), no primeiro posfácio do livro “1984", de George Orwell, o colapso do mundo medieval levou a uma nova forma de escrever e sua primeira manifestação foi exatamente a utopia (também chamada "nãolugar”) de Thomas More durante o Renascimento:

A Utopia de Thomas More combinou uma crítica penetrante da própria sociedade do autor, de sua irracionalidade e de sua injustiça, com o retrato de uma sociedade que, apesar de não ter alcançado talvez a perfeição, resolvera a maior parte dos problemas humanos que pareciam sem solução para seus contemporâneos. (FROMM 1961: 366).

A percepção renascentista da força e da esperança na perfeição individual e social do homem se manteve inabalada até o período pós-Primeira Guerra Mundial, o qual, a partir de sua insensibilidade moral, inaugurou o que Fromm (1961) chama de destruição da tradição ocidental de esperança, que foi ainda mais consolidada com outros eventos que se seguiram, como a grande depressão de 1929, o terror stalinista dos anos 30 e a Segunda Guerra Mundial, por exemplo. 
Foi nesse contexto que surgiu a distopia, que se comporta como uma “utopia negativa”, já que apresenta uma ideia oposta àquela do termo criado por Thomas More. Um mundo ou futuro distópico é caracterizado por uma sociedade baseada na opressão e no totalitarismo, onde não há espaço para o otimismo. Dessa forma, a distopia se fez presente no século XX como uma importante manifestação da ficção científica, já que houve, naquele período, condições "para a emersão de uma forma de pensar, imaginar e escrever sobre o futuro como um tempo no qual as coisas se tornariam piores" (KOPP ET AL 2013:83). Conforme defende Fromm (1961:369), “as utopias negativas expressam o sentimento de impotência e desesperança do homem moderno assim como as utopias antigas expressavam o sentimento de autoconfiança e esperança do homem pós-medieval".

Assim, as obras de distopia já no século XX tinham um caráter de crítica política e social, alertando os leitores "contra uma sociedade manipuladora e projetada num futuro até então fictício, mas não impossível”, conforme discutido por Silva (2016:28). Segundo Kopp et al (FogG APUD KoPP ET AL 2013:84), tais obras "são predominantemente extrapolações daquilo que os escritores sentem que são efeitos destrutivos e desumanizantes da tecnologia e das mudanças tecnológicas”.

No prefácio de “Laranja Mecânica” (2014 [1962]), de Anthony Burgess, o tradutor Fábio Fernandes menciona a chamada "trindade distópica", que exalta a ficção científica do século XX e seus cenários apocalípticos. Fazem parte dessa trindade, além do próprio “Laranja Mecânica”, “1984”, de George Orwell, e "Admirável Mundo Novo", de Aldous Huxley, três das mais importantes obras de distopia de todos os tempos.

“Laranja Mecânica” conta a história de uma gangue de adolescentes delinquentes que, liderados pelo protagonista Alex, roubam e estupram, fazendo uso de violência extrema. Ao cair nas mãos da polícia, Alex vê toda a agressividade com a qual agia voltar em resposta por parte do governo totalitário: ele é usado como cobaia numa experiência criada pelo Estado, chamada "Tratamento Ludovico", uma terapia de aversão voltada para conter os impulsos destrutivos de delinquentes. 
Já "Admirável Mundo Novo" (1932) narra a história de uma sociedade na qual os indivíduos são condicionados, seja de forma genética ou de forma biológica e psicológica (isto é, ao ingerir alimentos e bebidas misturados a certas substâncias), a aceitar as regras vigentes impostas por um estado autoritário. Dividida em castas, a população não sofre repressão ou violência nas mãos do governo, uma vez que o mesmo controla o comportamento e sentimento humanos através da substância "Soma", destinada a induzir as pessoas a se sentirem felizes e conformadas.

Por fim, “1984” (1949), do ensaísta e romancista britânico George Orwell, gira em torno de um mundo sombrio e opressivo, no qual ninguém escapa à vigilância da autoridade suprema, o Grande Irmão ou Big Brother, "a mais famosa personificação literária de um poder cínico e cruel ao infinito" (Prefáclo, 2009 [1949]). Seja em lugares públicos ou nos metros quadrados mais íntimos de um lar, teletelas monitoram, vigiam e espionam o dia a dia da população londrina; nas ruas da cidade cartazes trazem o slogan "O Grande Irmão está de olho em você", o que mostra o quão desprovido de individualidade o homem é. Logo, vemos em "1984" uma característica distópica tal como discutido por Kopp et al (2013:85): “o homem perde a capacidade de definir o seu destino ou de ter consciência acerca dele".

As tensões vividas pela sociedade contemporânea em face de ameaças terroristas, conflitos separatistas, crises econômicas e políticas etc. tornaram o século XXI propício a dar continuidade à produção de obras distópicas, apesar de as tramas atuais introduzirem um elemento novo: o protagonista jovem na luta por uma sociedade mais justa. Percebe-se que tal elemento desempenha papel fundamental em atrair o público jovem, uma vez que esses leitores muitas vezes se identificam com histórias sem finais felizes, em que personagens jovens lidam não só com conflitos externos, mas também com conflitos internos relacionados ao período de adolescência e às suas próprias incertezas, inseguranças e desilusões.

Além disso, outro fator contribui para o alcance internacional de muitas obras de distopia: o incentivo do ramo cinematográfico, já que os livros de maior sucesso em seus países de origem chegam às telas do cinema em diversas partes do mundo. Logo, "assim como fora o século XX, o século XXI 
tem sido propício ao surgimento de novos livros que abordem as tensões pelas quais a população mundial tem passado, que suscitem críticas à sociedade e aos problemas que encontramos nela, e que mostrem possíveis caminhos, mesmo que de forma exagerada, que a humanidade pode acabar tomando" (SILVA 2016:29).

Dois dos mais recentes sucessos de distopia são as trilogias "Jogos Vorazes", de Suzanne Collins, e "Divergente", de Veronica Roth. Objeto do presente estudo, “Divergente” mostra uma Chicago pós-apocalíptica dividida em cinco facções, cada uma sendo responsável por cultivar uma virtude: a Abnegação valoriza o altruísmo; a Amizade preza a bondade; a Audácia cultiva a coragem; a Erudição, a inteligência e a tecnologia; e, por fim, a Franqueza é voltada para o cultivo da honestidade. Existem aqueles que não se encaixam em nenhuma facção, os chamados "sem-facção", pessoas marginalizadas que vivem em condições de miséria nas ruas da cidade. Há, ainda, aqueles que se encaixam em mais de uma facção, os chamados "Divergentes"; raros e considerados perigosos por não serem manipulados pelos soros de simulação criados pela Erudição, os Divergentes devem manter sua identidade em segredo e agir como os outros membros "normais" de suas facções, caso contrário, a Erudição pratica uma verdadeira caça às bruxas para identificálos, capturá-los e, muitas vezes, executá-los.

Vemos, assim, que o aspecto tecnológico continua presente nas distopias recentes, de maneira a retratar o perigoso papel da tecnologia se usada de forma errada por governos autoritários e abusivos. Logo, apesar de também existirem elementos diferentes entre as distopias do século XX e as novas distopias, tanto aquelas quanto estas servem como instrumento de crítica social "ao dar enfoque aos efeitos sofridos pela sociedade por conta de mudanças tecnológicas e governos abusivos e totalitários” (SILVA 2016:78).

Além disso, Silva discorre sobre o fato de a grande maioria das obras atuais de distopia ser produzida em países democráticos, o que, de certo modo, vai de encontro àquilo retratado nas tramas:

Apesar de os países produtores desse tipo de literatura, como os Estados Unidos, não estarem, nos dias de hoje, sofrendo diretamente as consequências advindas de governos autoritários e grupos extremistas, eles estão, até certo ponto, envolvidos em 
conflitos armados referentes a embates políticos, religiosos e ideológicos, o que pode estar estimulando muitos escritores a se dedicarem a essas obras distópicas, que expressam uma preocupação acerca do futuro da humanidade. (SILVA 2016: 78).

\section{Um olhar sobre o polissistema literário brasileiro atual: o papel da literatura juvenil distópica traduzida}

O polissistema literário, de acordo com a Teoria dos Polissistemas, postulada por Itamar Even-Zohar (1990 [1978]), é um sistema dinâmico e flexível, constituído de centro e periferia, que está sujeito a forças externas, sejam elas de natureza política, ideológica e/ou histórica, e também a forças internas, que podem ser de natureza poética ou estética. Esse polissistema está, ainda, constantemente em contato com outros sistemas do polissistema cultural, que é um conglomerado de sistemas que compõem a sociedade, estando também embutido nas estruturas ideológicas e socioeconômicas da mesma. Justamente por ser flexível, oposições internas e mudanças contínuas se fazem presentes na configuração do polissistema.

Even-Zohar, no texto The Position of Translated Literature within the Literary Polysystem (EVEN-ZoHAR 1990 [1978]), aponta para o não reconhecimento de possibilidades de a literatura traduzida existir como um sistema individual dentro do polissistema. Pelo fato de não receber o mesmo reconhecimento recebido pelas grandes literaturas e ser marginalizada quando comparada a elas, a literatura traduzida é tida como um sistema periférico dentro do polissistema. Isso quer dizer que ela não tem influência em processos significativos e é modelada a partir de normas já convencionalmente estabelecidas por uma literatura-alvo dominante.

Ocupar uma posição periférica no que diz respeito ao estudo da literatura, no entanto, não significa estar preso permanentemente na periferia do polissistema literário. Dessa forma, a literatura traduzida pode vir a ser deslocada para posições mais centrais e privilegiadas dentro do 
polissistema em determinadas situações, que, segundo Even-Zohar, são três: quando a literatura ainda está em formação, resultando em um polissistema não-cristalizado; quando o próprio sistema literário é considerado fraco e periférico; e quando há um vácuo literário no sistema, ou seja, quando não há mais o que ser explorado, seja por crises no sistema, por esgotamento de modelos estéticos ou por censura de caráter político-ideológico. É importante lembrar que, caso o deslocamento aconteça, seja da periferia para o centro ou vice-versa, nem todos os tipos de literatura traduzida terão, obrigatoriamente, o mesmo destino dentro do polissistema.

Argumentamos assim, que o polissistema literário brasileiro, por não poder contar com uma produção sistemática de obras distópicas nacionais, acaba dependendo dos mecanismos de importação para suprir o "vácuo" literário no que diz respeito ao subgênero aqui em questão, e tal tentativa de preenchimento desse vácuo se dá via literatura traduzida, uma vez que os Estados Unidos têm atuado como um dos maiores produtores de distopia nos últimos anos. Como essas obras importadas advêm de um sistema literário bastante rico e já cristalizado, e que goza de prestígio internacionalmente, acreditamos que elas tendem a alcançar posições mais centrais dentro do polissistema literário nacional.

Azenha Jr. (2015) ratifica essa tendência, ao refletir sobre as relações entre literatura infantil e juvenil e os Estudos da Tradução, reconhecendo a existência de uma

(...) rede de condicionantes para os agentes mais próximos do processo - leitores que colaboram com editoras, editores, críticos, educadores, pais, entre outros-, bem como para uma geopolítica que, ao longe, determina as estratégias de produção e de recepção de textos escritos e traduzidos para a criança e o jovem. Esse processo complexo dependeria, então, em última análise, de aspectos econômicos, jurídicos, administrativos, e educacionais, de que resultariam relações de forças entre os países e sua posição como centros ou periferias de sistemas literários. (AZENHA JR. 2015: 219)

São tantas as trilogias e sagas distópicas de sucesso internacional trazidas para solo brasileiro, como, por exemplo, as trilogias "Divergente" 
(Veronica Roth), “Jogos Vorazes" (Suzanne Collins), "A Rainha Vermelha" (Victoria Aveyard), "O Teste" (Joelle Charbonneau), e as sagas "The Maze Runner" (James Dashner) e "A Seleção" (Kiera Cass), que o interesse das editoras nacionais em investir na tradução e publicação de tais livros não só é compreensível como justificável.

Além disso, "novas forças literárias advindas de outros países não só ocupam os espaços deixados pela ausência de certos gêneros e/ou subgêneros, como a distopia, dentro do polissistema, mas também influenciam e impulsionam autores nacionais a produzir obras que façam parte dessas tendências." (SILVA 2016: 39). No Brasil, já foram publicadas duas séries distópicas nacionais: "Anômalos", de Bárbara Moraes, e "Supernova", de Renan Carvalho. Ainda assim, a produção nacional de distopia é ainda muito jovem e escassa, e, considerando que a maior parte das obras desse subgênero é importada dos Estados Unidos, como previamente destacado, "modelos estrangeiros acabam por ter fácil acesso ao nosso polissistema, tornando o mesmo suscetível a sofrer mudanças no que diz respeito à posição ocupada por essa literatura juvenil traduzida." (SILVA 2016: 42).

\section{As escolhas do tradutor e a ética na tradução: uma análise da trilogia "Divergente"}

Face às pressões ideológicas e estéticas (Even-ZoHAR 1990 [1978]) ou, nos termos de Lefevere (1992b), ideológicas e poetológicas, manifestas em mecanismos de manipulação e patronagem (LeFEVERE 1992B) a que o polissistema cultural e, por extensão, o polissistema literário estão sujeitos, é fundamental reconhecer o lugar do tradutor como participante ativo do polissistema e, dessa forma, avaliar suas escolhas tradutórias dentro desse contexto de múltiplas variáveis. Nas palavras de Lefevere: 
A patronagem pode ser exercida por pessoas, tais como os Medici, Mecenas ou Luís XIV, e também por grupos de pessoas, um corpo religioso, um partido político, uma classe social, uma corte real, editoras e, por último, mas não a menos importante, a mídia, tanto as revistas e jornais quanto as maiores corporações de televisão. Os patrocinadores tentam regular a relação entre o sistema literário e os outros sistemas que, juntos, formam a sociedade, a cultura. Via de regra, eles operam por meio de instituições estabelecidas para regularem, senão a escrita da literatura, pelo menos sua distribuição: academias, agências de censura, revistas críticas e, de longe o mais importante, os estabelecimentos de ensino. (LEFEVERE 1992B: 4)

No que diz respeito à tradução, é importante destacar que quaisquer que sejam as escolhas e estratégias tradutórias utilizadas pelo profissional tradutor durante seu trabalho, tendo ele sofrido influências externas ou não, elas são conscientes. Oittinen (2006) explicita seu ponto de vista em relação à tradução ao afirmar que, para ela, todos os textos e todas as traduções estão direcionados aos seus leitores e ouvintes, ao mesmo tempo em que esses leitores e ouvintes também estão direcionados aos textos e traduções. Existe nessa relação um desejo mútuo de entender e ser entendido e um senso de responsabilidade, uma vez que o leitor é ativo e responsável por aquilo que lê e entende. Assim, motivado por seu próprio senso de responsabilidade como leitor, o tradutor deve fazer das palavras do texto fonte suas próprias palavras. Como os textos traduzidos refletem as intenções, os sentimentos e os valores morais do tradutor, a prática de tradução é uma questão inerentemente ética. Para Oittinen (2006), as razões por trás das mais diversas soluções postas em prática pelo tradutor se encontram não só nas diferentes estratégias utilizadas, como também nos diferentes públicos para os quais se traduz e nas diferentes visões que o tradutor tem da história como um todo. Além disso, como mencionado anteriormente, o fator estético é outro componente importante que rege o sistema literário e que pode estar relacionado a pressões sofridas pelo polissistema, refletindo-se, assim, em muitas das escolhas do tradutor, de forma a adequar, da melhor maneira possível, o texto traduzido à cultura alvo, via língua e estruturas gramaticais, mesmo que essas escolhas e mudanças impliquem o apagamento de traços da 
obra original, de seu contexto de produção e da cultura fonte que poderiam até mesmo ser mantidos.

Berman (2013 [1985]:63), por sua vez, ao escrever sobre a analítica da tradução na prosa literária, reconhece que o tradutor está exposto a um jogo de forças e que "a analítica propõe colocar em evidência essas forças e mostrar os pontos sobre as quais elas agem”. Nessa perspectiva, Berman elenca uma série de tendências deformadoras que, segundo ele, "formam um todo sistemático, cujo fim é a destruição, não menos sistemática, da letra ${ }^{1}$ dos originais, somente em benefício do 'sentido' e da 'bela forma'.” (2013 [1985]: 67).

Dentre as treze tendências descritas por Berman (2013 [1985]), abordamos, a seguir, duas das que se apresentam de forma mais sistemática, para adotar um termo do próprio autor, na trilogia analisada, que são $a$ destruição das redes subjacentes e a destruição dos sistematismos da obra original. Vejamos cada um desses casos:

\subsection{A destruição das redes significantes subjacentes}

$\mathrm{Na}$ definição de Berman, a destruição das redes significantes subjacentes ocorre quando o texto traduzido não reproduz as chamadas redes significantes, redes essas que consistem de significantes combinados entre si, formando um texto subjacente à obra, um subtexto. No original, por mais que as palavras pareçam não significar nada quando analisadas sozinhas, elas fornecem uniformidade e sentido à obra como um todo.

A presença dessa tendência deformadora em nossa análise se deu, principalmente, por meio das escolhas lexicais feitas pelo tradutor nos três volumes da trilogia. Pudemos perceber que, muitas vezes, palavras e expressões de carga semântica mais forte ou incisiva foram atenuadas na tradução, o que nos faz pensar que a mesma vai em direção a um modelo conceptual diferente daquele proposto na obra original, que se trata de um modelo bélico e agressivo em um contexto de conflitos, por estar relacionado a uma situação de hierarquia entre facções em disputa por poder. Levando em

\footnotetext{
${ }^{1}$ Berman (2013 [1985]:34) define letra da seguinte forma: "A letra é seu espaço de jogo".
} 
consideração tal relação de poder, a linguagem do original se faz compatível com o papel exercido por cada personagem na história, e o fato de a tradução apresentar uma atenuação dessa linguagem, às vezes fazendo uso de verbos modais, acaba por alterar o tom pretendido pela autora.

Vejamos abaixo um primeiro exemplo da ocorrência dessa tendência no livro "Divergente", o primeiro da trilogia:

I stare into my own eyes for a moment. Today is the day of the aptitude test that will show me which of the five factions I belong in. And tomorrow, at the Choosing Ceremony, I will decide on a faction; I will decide the rest of my life; I will decide to stay with my family or abandon them. ( ROTH 2011: 2, grifo nosso).
Por um momento, encaro meus olhos no espelho. Hoje é o dia do teste de aptidão que me mostrará a qual das cinco facções eu pertenço. $E$ amanhã, na Cerimônia de Escolha, escolherei uma; escolherei 0 caminho que vou trilhar pelo resto da minha vida; escolherei se devo ficar com minha família ou abandoná-la. (Rотн 2012в: 8, grifo nosso).

No trecho acima, no qual a protagonista, Tris, reflete sobre os eventos dos próximos dias, que darão rumo à sua vida, percebemos que a tradução de "will decide" (literalmente "decidirei") como "escolherei" ameniza um pouco o poder que está sendo dado à personagem para que ela decida seu futuro e lide com as consequências inerentes a qualquer que seja sua decisão. Parecenos possível argumentar que o tradutor tenha optado pelo verbo "escolher" por influência de "Cerimônia de Escolha" ("Choosing Ceremony", no original), um dos eventos do qual a personagem participará. No entanto, vemos que a autora da trama original não faz tal relação, uma vez que opta pelo verbo "to decide" ("decidir", "determinar", de acordo com o Dicionário Oxford de língua inglesa) em vez de "to choose" ("escolher", "selecionar", "preferir", de acordo com o mesmo dicionário). 
No segundo exemplo, retirado do livro "Insurgente", temos outro caso de atenuação da linguagem na tradução, correlacionada aos papeis das personagens na trama:

\begin{tabular}{|l|l|}
\hline "Wait," he says. "I have a request." & - Esperem. Tenho um pedido a \\
"We don't take requests from & fazer. \\
criminals," says Tori. She's standing & - Não aceitamos pedidos de \\
on one leg, and has been for the & criminosos - diz Tori. Ela está em pé \\
past few minutes. She sounds tired - & sobre uma perna só há alguns \\
she probably wants to get this over & minutos. Sua voz soa cansada. Ela \\
with so she can sit down again. To & provavelmente quer acabar logo \\
her this execution is just an & com isso, para poder sentar-se \\
inconvenience. & novamente. Para ela, a execução é \\
“I am a leader of Dauntless," he & apenas uma inconveniência. \\
says. "And all I want is for Four to & - Sou um líder da Audácia. E tudo o \\
be the one who fires that bullet." & que peço é que Quatro seja a pessoa \\
"Why?" Tobias says. & a atirar. \\
"So you can live with the guilt," Eric & - Por quê? - pergunta Tobias. \\
replies. "Of knowing that you & - Para que você seja obrigado a \\
usurped me and then shot me in the & viver com a culpa - responde Eric. - \\
head." (ROTH 2012a: 273-274, grifo & De saber que você usurpou o meu \\
nosso). & posto e depois atirou na minha \\
cabeça. (RotH 2013B: 270, grifo \\
nosso).
\end{tabular}

Nesse segmento, vemos, novamente, a quebra da relação hierárquica de poder exercida por determinadas personagens, que aqui é revelada na tradução de "want" (literalmente "querer", ou, neste caso, "quero") por "peço". Antes de ser executado, Eric, um dos líderes traidores da Audácia, tem um último pedido a fazer, o qual diz respeito a quem tirará sua vida. Por ser um dos líderes da facção, apesar de agora ser considerado um "ex-líder", ele ainda possui autoridade para escolher a pessoa a atirar. Ao optar pelo verbo "want", a autora aponta para o caráter de exigência de seu pedido, 
uma vez que a posição ocupada pela personagem ainda the permite exigir tal coisa. Na tradução, porém, a atenuação de "want" por "pedir" em "E tudo o que peço (...)" apaga a marca de prestígio inerente ao posto que Eric, até então, ocupava na facção. Segundo o Minidicionário Silveira Bueno (2007), "querer" pode significar "ter vontade", "ter intenção", "pretender", "ambicionar", enquanto "pedir" pode significar "rogar”, “mendigar”, "implorar", "suplicar”, "solicitar".

No terceiro exemplo, a seguir, também retirado do livro "Insurgente", temos as seguintes ocorrências:

She presses the plunger down. Peter leans forward and looks into my eyes.

"The serum will go into effect in one minute," he says. "Be brave, Tris."

The words startle me, because that is exactly what Tobias said when he put me under my first simulation. My heart begins to race.

Why would Peter tell me to be brave? Why would he offer any kind words at all?

All the muscles in my body relax at once. A heavy, liquid feeling fills my limbs. If this is death, it isn't so bad. My eyes stay open, but my head drops to the side. I try to close my eyes, but I can't - I can't move.

Then the heart monitor stops beating. (ROTH 2012a: 384-385, grifo nosso).
Ela injeta o soro. Peter inclina-se para a frente e olha nos meus olhos. - O soro fará efeito em um minuto. Seja corajosa, Tris.

Suas palavras me surpreendem, porque são exatamente o que Tobias disse quando me colocou sob minha primeira simulação.

Meu coração começa a disparar.

Por que Peter pediria para eu ser corajosa? Por que ele me ofereceria qualquer palavra gentil?

Todos os músculos do meu corpo relaxam ao mesmo tempo. Meus membros ficam pesados. Se isso é a morte, não é tão ruim assim. Meus olhos permanecem abertos, mas minha cabeça desaba para o lado. Tento fechar os olhos, mas não consigo. Não consigo me mover. De repente, o monitor cardíaco para de apitar. (Rотн 2013в: 377, grifo nosso). 
No trecho acima, Tris está prestes a ser executada na sede da Erudição e Peter, um ex-membro da Audácia que agora trabalha para Jeanine, é designado para acompanhar todo o processo. Destacamos a atenuação da linguagem no texto traduzido em dois momentos distintos: as palavras de Peter, tão inesperadas por parte de Tris, não apenas "surpreendem" a personagem, como mostra a tradução, mas, mais do que isso, a colocam em um “estado de alerta”, ao espantá-la, de acordo com a opção da autora pelo verbo "startle" (segundo o Dicionário Oxford, "startle" significa “sobressaltar"), representando todo o conflito presente na relação conturbada entre as duas personagens; além disso, quando o tradutor opta por traduzir "tell” (literalmente “dizer” ou mesmo “ordenar") como “pediria”, a relação de poder entre as duas personagens passa despercebida se levarmos em consideração a posição que, naquele momento da trama, cada um deles exerce (Tris como prisioneira da Erudição e Peter como um dos “homens de confiança” da líder Jeanine).

\subsection{A destruição dos sistematismos}

A destruição dos sistematismos, por sua vez, pode ser verificada quando a racionalização, a clarificação e o alongamento $^{2}$ são empregados, visando tornar o texto mais homogêneo que o original, o que acaba por destruir o sistema ao introduzir elementos que o mesmo exclui.

De acordo com Berman, a destruição dos sistematismos de uma obra ultrapassa o nível dos significantes, já que alcança os tipos de frases e construções utilizadas no texto traduzido. A destruição dos sistematismos leva a tradução a ser assistemática, e mesmo que essa assistematicidade esteja escondida e diluída na tradução, a inconsistência do texto traduzido ainda é perceptível.

\footnotetext{
${ }^{2}$ A racionalização, a clarificação e o alongamento também são tendências deformadoras da letra que, na concepção de Berman (2013 [1985]), correspondem à linearização das estruturas sintáticas, à clareza de palavras e sentidos e ao afrouxamento rítmico da obra, respectivamente.
} 
Em nossa análise de dados, a presença dessa tendência deformadora se deu através do apagamento de marcas de discurso direto que evidenciam o foco narrativo, como citações diretas do tipo "I say" ("digo") e "He says" ("diz ele"), por exemplo, que aparecem depois das falas dos personagens. Gomes e Franco (2008) explicam, com base em Sanders e Redeker (1996), que "o ato de narrar e o de focalizar coincidem na pessoa do narrador; portanto, sua voz está sempre presente, ora mais ora menos explícita" (GOMES; Franco 2008: 157). Vemos em nossa análise que, de fato, há momentos em que a presença do narrador fica menos explícita, principalmente quando as citações de discurso direto são apagadas na tradução. De acordo com Gomes e Franco (2008:160), "tais citações são usadas com o intuito de incrementar a objetividade percebida e a exatidão do relato para o leitor".

Moisés (1987 [1969]), por sua vez, observa que, quando relativo ao emprego da primeira pessoa, o foco narrativo, também chamado ponto de vista, divide-se em dois: a história pode ser relatada pela personagem principal, ou pode ser comentada por uma personagem secundária que está ciente do drama do protagonista.

Foram selecionados trechos do segundo livro da trilogia, "Insurgente", no qual a presença da tendência deformadora em questão é recorrente, e também do terceiro livro da trilogia, "Convergente", apesar de as ocorrências aparecerem em menor escala. Em "Divergente”, contudo, não foram encontrados exemplos relacionados ao ponto de vista, o que nos mostra que não houve um padrão adotado na tradução dos três livros que compõem a trilogia. Vejamos, então, um primeiro exemplo escolhido e retirado de "Insurgente":

\begin{tabular}{|l|l|}
\hline Tobias and I sit on the edge of the & Tobias e eu nos sentamos na beirada \\
car with our legs dangling over the & do vagão, com as pernas balançando \\
edge. & para fora. \\
"Do you know who it is?" & - Você sabe quem é? \\
Tobias nods. & Tobias assente com a cabeça. \\
"Who, then?" & - Quem é, então? \\
"It's hard to explain,” he says. “I & - É difícil explicar. Preciso the \\
\hline
\end{tabular}




\begin{tabular}{|c|c|}
\hline $\begin{array}{l}\text { have a lot to tell you." } \\
\text { I lean against him. } \\
\text { "Yeah," I say. “So do I." (RоTH } \\
\text { 2012a: 91-92, grifo nosso). }\end{array}$ & $\begin{array}{l}\text { contar muitas coisas. } \\
\text { Apoio o meu corpo contra o dele. } \\
\text { - É. Eu também. (RoTH 2013B: 97). }\end{array}$ \\
\hline
\end{tabular}

As marcas linguísticas "he says" ("diz ele", em português) e "I say" (“digo") não só fazem parte da organização da narrativa tal como descrita em primeira pessoa ao longo de toda a trama, mas também evidenciam o papel de testemunha assumido pela personagem, dando ao leitor, ainda, a ideia de que a história possa estar sendo relatada num momento posterior aos acontecimentos. Ao apagar esses marcadores do discurso direto na tradução, argumentamos que a personagem se projeta na cena como se a ação se desenrolasse simultaneamente à narrativa, o que também aproxima o leitor da cena.

Em um segundo exemplo, retirado de "Convergente", temos as seguintes ocorrências:

\begin{tabular}{|c|c|}
\hline $\begin{array}{l}\text { "This may be a bad time," he says, } \\
\text { "but there's something I want to say } \\
\text { to you." } \\
\text { I tense immediately, afraid that he's } \\
\text { going to name some crime of mine } \\
\text { that went unacknowledged, or a } \\
\text { confession that's eating away at } \\
\text { him, or something equally difficult. } \\
\text { His expression is unreadable. } \\
\text { "I just want to thank you," he says, } \\
\text { his voice low. "A group of scientists } \\
\text { told you that my genes were } \\
\text { damaged, that there was something } \\
\text { wrong with me-they showed you } \\
\text { test results that proved it. And even }\end{array}$ & $\begin{array}{l}\text { - Talvez não seja o melhor } \\
\text { momento, mas quero dizer uma } \\
\text { coisa. } \\
\text { Na mesma hora, fico tensa, temendo } \\
\text { que ele cite algum crime meu que } \\
\text { passou despercebido, uma confissão } \\
\text { que o está corroendo por dentro ou } \\
\text { algo igualmente difícil. Não consigo } \\
\text { decifrar a sua expressão. } \\
\text { - Só quero agradecer - diz ele em } \\
\text { voz baixa. - Um grupo de cientistas } \\
\text { disse a você que meus genes eram } \\
\text { danificados, que havia algo de } \\
\text { errado comigo, e mostraram } \\
\text { resultados de testes como prova. E }\end{array}$ \\
\hline
\end{tabular}




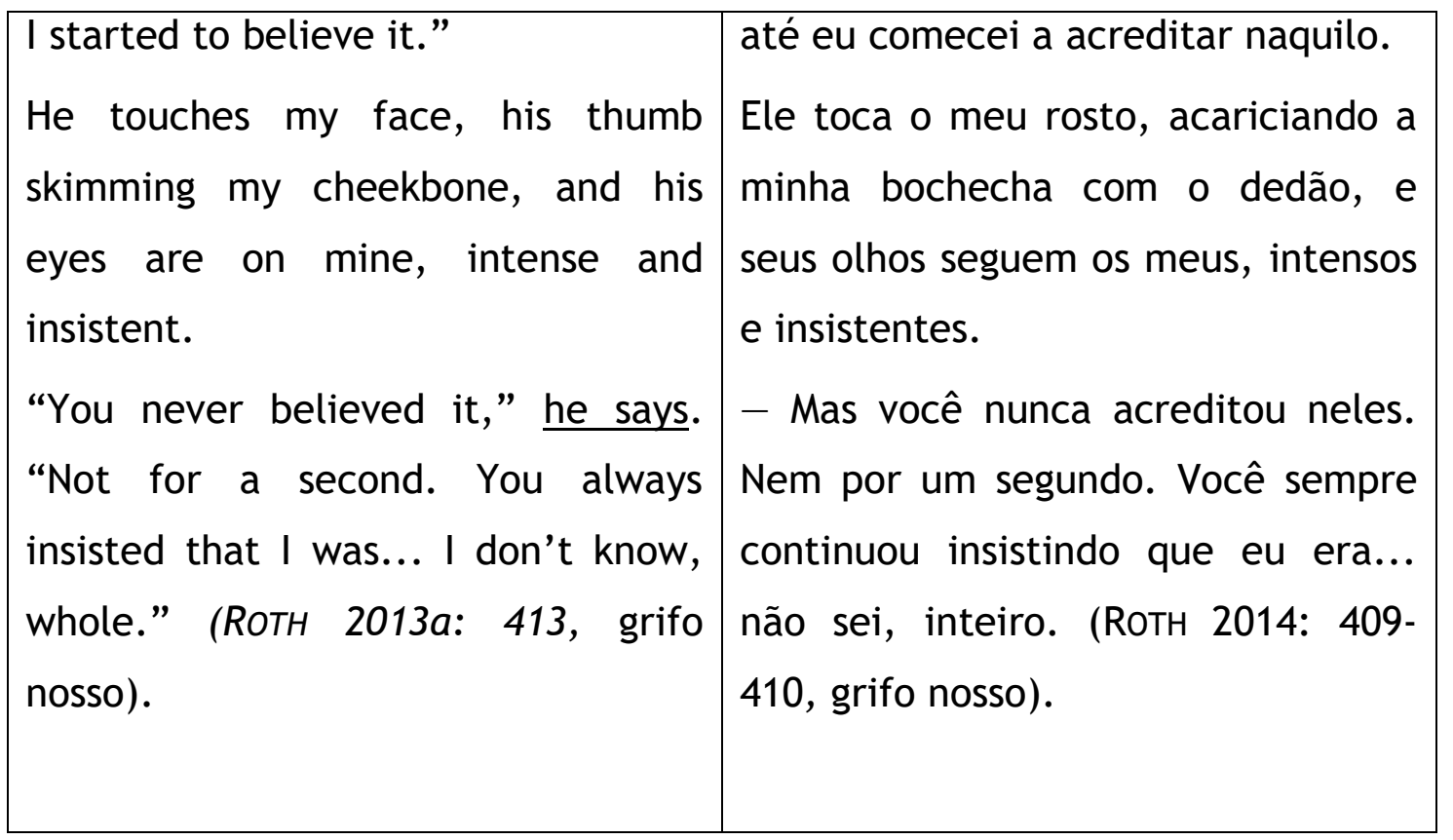

No segmento acima, referente a um diálogo entre Tris e Tobias, ambos os marcadores de discurso de terceira pessoa (“he says") são retirados na tradução, mais uma vez projetando a personagem Tris, que narra o capítulo em questão, como mera personagem na cena, que parece estar sendo narrada concomitantemente aos acontecimentos. Assim, ao apagar as marcas do discurso direto, o plano narrativo e o plano da ação ficam sobrepostos, o que faz com que o leitor perca a noção de que Tris é também testemunha, e não só uma personagem participando ativamente da cena. No entanto, há, ainda, uma ocorrência de marcador do discurso acompanhado de uma expressão informativa ("he says, his voice low"), que foi mantido no texto traduzido como “diz ele em voz baixa". Logo, vemos que a informatividade dessa expressão e o sentido que ela dá ao marcador de discurso direto leva o tradutor a manter todo o segmento na tradução.

Por fim, temos um terceiro grupo de ocorrências, retirado do livro “Convergente”, para ilustrar nossa análise:

\begin{tabular}{|l|l|l|}
\hline “You are not special," I say. “I like & - Você não é especial. Também \\
to hurt people too. I can make the & gosto de machucar as pessoas. \\
cruelest choice. The difference is, & Consigo tomar decisões cruéis. A \\
sometimes I don't, and you always & diferença é que, às vezes, não é isso \\
& que faço. Mas você sempre age \\
\hline
\end{tabular}


do, and that makes you evil."

I step over him and start down Michigan Avenue again. But before I take more than a few steps, I hear his voice.

“That's why I want it," he says, his voice shaking.

I stop. I don't turn around. I don't want to see his face right now.

"I want the serum because I'm sick of being this way," he says. "I'm sick of doing bad things and liking it and then wondering what's wrong with me. I want it to be over. I want to start again." (ROTH 2013a: 451, grifo nosso). assim, e é isso que o torna mau.

Passo por cima dele e volto a seguir pela Avenida Michigan. Dou apenas alguns passos antes de ouvir sua voz. - É por isso que eu quero o soro diz ele com a voz trêmula.

Eu paro, mas não me viro. Não quero ver o rosto dele agora.

- Quero o soro porque estou cansado de ser assim. Estou cansado de fazer coisas ruins e gostar disso e, depois, ficar me perguntando o que há de errado comigo. Quero que isso acabe. Quero recomeçar. (RoTH 2014: 447, grifo nosso).

Neste exemplo, temos, no texto original, duas ocorrências de marcas do discurso direto que são apagadas na tradução, tanto em primeira pessoa ("I say") quanto em terceira ("he says"), mais uma vez removendo a evidência do plano narrativo, o que leva a personagem, testemunha e participante da cena, a ter menos destaque e visibilidade. Além disso, é possível observar que, mais uma vez, quando há expressões acompanhando a construção verbal e reforçando seu sentido, como em "he says, his voice shaking", o tradutor opta pela sua manutenção. Por fim, é importante destacar que o capítulo referente ao trecho acima não é narrado pela personagem Tris, mas sim por Tobias, o que nos mostra que os procedimentos de apagamento de marcas de discurso direto continuam mesmo quando há a troca de narrador.

Ao analisarmos a destruição das redes subjacentes, constatamos que nos três livros há, na tradução, uma atenuação da linguagem utilizada nas interações verbais, algumas vezes a partir do uso de verbos modais. Dessa maneira, o caráter bélico da história, por se tratar de uma sociedade dividida 
em facções, na qual determinados indivíduos estão dotados de mais poder e autoridade do que outros, acaba sendo diluído, e muitas vezes perdido, quando o tradutor opta por palavras e expressões de carga semântica mais leve. Essas escolhas tradutórias culminam com a incompatibilidade entre o tom conferido à tradução e o tom pretendido pela autora da trilogia.

No que tange à destruição dos sistematismos da obra, o apagamento de marcadores de discurso direto na tradução, tais como "I say", "he says" e "she says", de um modo geral, reflete, em determinados momentos, uma sobreposição dos planos de ação e narração, de modo que o leitor não consegue separar a voz da personagem como narradora da voz da personagem como participante ativa da cena. Em outros momentos, parece ficar evidente para o leitor que a narração da personagem retrata um acontecimento passado, como se ela estivesse apenas retomando aquilo em sua mente; houve, também, momentos em que o leitor foi aproximado do evento descrito na cena, como se aquilo estivesse acontecendo e se desdobrando ao longo da própria leitura.

Ao procurarmos avaliar essas escolhas em face da dinâmica de forças que opera no polissistema de uma determinada cultura, é possível argumentarmos que o tradutor faz escolhas com base em mecanismos de patronagem (LEFEVERE 1992B), na medida em que se vê pressionado a respeitar as ordens político-ideológicas e estéticas vigentes, sejam elas ditadas pelas editoras ou pelo público-alvo. Da mesma forma, os demais sistemas que coexistem ao sistema literário (EVEN-ZoHAR 1990 [1978]), pressionam esse mesmo polissistema, possivelmente levando o tradutor a adotar estratégias de tradução compatíveis com o sistema linguístico e cultural da língua traduzida, culminando, porém, na deformação da letra original (BERMAN 2013 [1985]).

\section{Considerações Finais}

Neste artigo, propusemo-nos a discutir o papel da literatura juvenil traduzida, em especial do subgênero distopia, dentro do polissistema literário e cultural brasileiro, tomando como base para nossa análise a trilogia escrita 
pela autora norte-americana Veronica Roth, intitulada Divergente, composta pelos volumes originais Divergent, Insurgent e Allegiant, traduzidos para 0 português brasileiro como "Divergente", "Insurgente" e "Convergente", respectivamente.

Tomamos como ponto de partida a teoria dos polissistemas (EVEN-ZOHAR 1990 [1978]) ao argumentar que a demanda de tradução de distopia acaba por pressionar o polissistema literário brasileiro para uma reconfiguração da posição ocupada pela literatura juvenil, e pautamo-nos nos conceitos de manipulação e patronagem (LEFEVERE 1992B) ao relacionar o contexto sóciopolítico-ideológico atual não só às escolhas das obras a serem traduzidas, mas também às escolhas tradutórias realizadas pelo tradutor responsável pela trilogia em questão, de maneira a verificar que tais escolhas estão diretamente relacionadas aos demais sistemas que constituem o polissistema cultural nacional e que pressionam o sistema literário, culminando no que Berman (2013 [1985]), em sua analítica da tradução, classificou de tendências deformadoras da letra, assumidas conscientemente pelo tradutor na dinâmica de traduzir.

Destacamos, assim, duas tendências que foram mais fortemente observadas no corpus analisado, composto de excertos dos três livros que compõem a trilogia "Divergente". Foram elas a destruição das redes significantes subjacentes e a destruição dos sistematismos. A destruição das redes significantes subjacentes foi observada no apagamento do subtexto que perpassa a trilogia e que diz respeito ao uso da linguagem por parte das personagens. Face às relações hierárquicas invocadas pelo modelo de facções em conflito por poder, tal como retratado pela trilogia, a linguagem é mais direta e menos polida, refletindo as relações de poder entre as personagens. $\mathrm{Na}$ tradução, a linguagem é invariavelmente atenuada e muitas vezes modalizada, refletindo, por sua vez, um modelo de relações hierárquicas bem mais flexível, compatível com a moldura cultural em que a língua da tradução se insere.

$\mathrm{Na}$ destruição dos sistematismos da obra original, por sua vez, percebemos uma característica sistemática na obra que é o uso do discurso direto na narrativa, que tem, ao longo da trilogia, dois narradores distintos - 
Tris e Tobias. Em ambas as situações, as marcas do discurso direto, que variam entre as formas "I say", "He says" e "She says", são sistematicamente apagadas na língua da tradução, operando o que argumentamos ser uma tentativa de sobreposição dos planos de narração e de ação, com o efeito de aproximar o leitor ainda mais da cena narrada.

Finalmente, defendemos que, por não figurar entre os países produtores de distopia e apresentar um vácuo literário em relação ao subgênero em questão (EvEN-ZoHAR 1990 [1978]), o Brasil depende da importação dos sucessos, sobretudo vindos do mercado anglo-saxônico, para suprir a demanda interna. Desse modo, como o polissistema literário da cultura anglo-saxônica goza de prestígio (AZENHA JR. 2015), as obras importadas para o mercado nacional e traduzidas para o português brasileiro tendem, consequentemente, a assumir posições mais privilegiadas dentro de nosso polissistema, que é pressionado para uma reconfiguração da posição da literatura juvenil em face à crescente entrada de livros juvenis distópicos no país com o intuito de ocupar o vácuo literário existente para esse subgênero em solo nacional.

Esperamos, com o presente artigo, contribuir para a reflexão sobre uma possível reconfiguração da posição periférica da literatura juvenil dentro do polissistema literário brasileiro, em face ao crescente consumo de literatura juvenil traduzida pelo segmento jovem e adulto, em especial do subgênero distopia, cuja produção nacional começa a ser estimulada a partir da tradução de obras do gênero provenientes de polissistemas mais centrais e hegemônicos. 


\section{Referências}

Berman, A. A tradução e a letra ou o albergue do longínquo. Trad. MariaHélène Torres et al. Florianópolis: PGET/UFSC, 2013 [1985].

Burgess, A. Laranja Mecânica. Trad. Fábio Fernandes. São Paulo: Editora Aleph, 2014[1962].

Carvalho, B. V. A literatura infantil: visão histórica e crítica. $4^{\text {a }}$ ed. São Paulo: Global Editora, 1985.

Coelho, N. N. Panorama histórico da literatura infantil/juvenil. São Paulo: Editora Ática S.A., 1991 [1984].

Even-Zohar, I. The Position of Translated Literature within the Literary Polysystem. In: HOLMES, J. S. et al (Ed.) Literature and Translation: New Perspectives in Literary Studies. Leuven: Acco, 1979.

GHESQUIERE, R. Why Does Children's Literature Need Translations? In: COILLIE, J. V.; VERSCHUEREN, W. P. (Ed.). Children's Literature in Translation: Challenges and Strategies. Manchester, UK \& Kinderhook, USA: St. Jerome Publishing, 2006. p. 19-32.

Gomes, S.; Franco, M. B. Cognição e discurso direto em narrativas fantásticas. In: SILVA, G.; ROCHA, L. F. M. (Org.). Quem conta um conto de fadas... Uma introdução ao mundo da fantasia. Rio de Janeiro: Confraria do Vento, 2008. p. 155-163.

HERMANS, T. The Manipulation of Literature: Studies in Literary Translation. London, Sydney: Croom Helm, 1985.

HuXley, A. Admirável Mundo Novo. Trad. Lino Vallandro. São Paulo: Globo/Biblioteca Azul, 2014[1932].

LEFEVERE, A. Translation, rewriting and the manipulation of literary fame. London: Routledge, $1992 \mathrm{~b}$.

MoISÉs, M. A análise literária. 5. ed. São Paulo: Editora Cultrix, 1977.

Neumann, A. L.; Silva, T. A. C.; Kopp, R. Comunicação e educação na literatura distópica: de Nós (1924) a Jogos Vorazes (2008). Revista Jovens Pesquisadores, Santa Cruz do Sul, v. 3, n. 1, p. 80-96, 2013. Disponível em: <http://www.online.unisc.br/ seer/index.php/jovenspesquisadores>. Acesso em: 29 abr. 2015.

OITTINEN, R. No Innocent Act: On the Ethics of Translating for Children. In: COILLIE, J. VERSCHUEREN, W. P. (Ed.). Children's Literature in Translation: Challenges and Strategies. Manchester, UK \& Kinderhook, USA: St. Jerome Publishing, 2006. p. 35-43. 
OrWELL, G. 1984. Trad. Heloisa Jahn. São Paulo: Companhia das Letras, 2009 [1949].

OXFORD. Dicionário Oxford Escolar para estudantes brasileiros de inglês. Oxford: Oxford University Press, 2010.

RotH, V. Divergent. 1.ed. New York: Katherine Tegen Books, 2011.

Roth, V. Insurgent. 1.ed. New York: Katherine Tegen Books, $2012 \mathrm{a}$.

Roth, V. Allegiant. 1.ed. New York: Katherine Tegen Books, $2013 a$.

Roth, V. Divergente. Trad. Lucas Peterson. Rio de Janeiro: Rocco Jovens Leitores, 2012b.

Roth, V. Insurgente. Trad. Lucas Peterson. Rio de Janeiro: Rocco Jovens Leitores, 2013b.

Roth, V. Convergente. Trad. Lucas Peterson. Rio de Janeiro: Rocco Jovens Leitores, 2014.

SILVA, N. R. Para além da divergência: o papel da literatura juvenil traduzida no polissistema literário brasileiro. Monografia de conclusão de curso do Bacharelado em Letras-Tradução-Inglês. Juiz de Fora: Departamento de Línguas Estrangeiras Modernas da UFJF, 2016, mimeo.

Silveira Bueno, F. (Ed.). Minidicionário da Língua Portuguesa. 2. ed. São Paulo: FTD, 2007.

Recebido em: 27/08/2017

Aceito em: 04/10/2018

Publicado em outubro de 2018 